\title{
Oral plasma zinc tolerance test in patients with protein energy malnutrition
}

\author{
Y ATALAY,* A ARCASOY, $†$ AND M KÜRKÇÜOĞLU* \\ ${ }^{*}$ Department of Paediatrics, Atatürk University, Erzurum, and †Zinc Deficiency and Treatment Research \\ Unit, Department of Paediatrics, Ankara University, Turkey
}

SUMMARY Zinc absorption was measured in 37 children with malnutrition using the oral zinc tolerance test $(22.5 \mathrm{mg}$ elementary zinc) and the results compared with those of a group of healthy control subjects. The increase in plasma zinc was significantly lower in patients with marasmic kwashiorkor than in the control group. The zinc tolerance test was, however, normal in marasmic patients.

We conclude that zinc deficiency occurs in some types of protein energy malnutrition, and that malabsorption may aggravate zinc deficiency. It is reasonable to give higher doses of zinc than are usually recommended during oral zinc supplementation in patients with protein energy malnutrition.

Protein energy malnutrition is still an important problem in many parts of the world. Certain clinical features are common to patients with protein energy malnutrition and those with zinc deficiency, including diarrhoea, anorexia, growth retardation, muscular atrophy, and a tendency to infections. This similarity has led many workers to study zinc absorption in patients with protein calorie malnutrition. Some found that plasma zinc concentrations were low, ${ }^{1}$ and others found decreased serum zinc concentrations in malnutrition, together with skin lesions. $^{23}$

Protein energy malnutrition is associated with various degrees of intestinal changes, which include gastrointestinal mucosal atrophy and structural alterations in the jejunal villi. ${ }^{48}$ Apart from inadequate dietary intake, digestive and absorptive defects may be important in the aetiology of protein energy malnutrition. It is, however, difficult to say whether these defects are causes or effects of the malnutrition.

The aim of this study was to determine whether there is a decrease in intestinal absorption of zinc in protein energy malnutrition in addition to preexisting zinc deficiency and malabsorption.

\section{Subjects and methods}

Thirty seven children (19 boys and 18 girls) aged between 5 months and 5 years with protein energy malnutrition were compared with 10 healthy chil- dren (eight boys and two girls) aged between 6 months and 5 years. The patients were classified according to the McLaren system. ${ }^{9}$

Routine laboratory tests were performed using standard methods. Serum alkaline phosphatase activities were measured (Sigma Diagnostics), and plasma and erythrocyte zinc concentrations were assessed by an atomic absorption spectrophotometer (Perkin Elmer Model 403). ${ }^{10}$ Blood samples $(4.5 \mathrm{ml})$ were collected using zinc free materials and anticoagulated with zinc free oxalate solution. Plasma was separated by centrifugation and the plasma zinc concentration determined using 3:1 dilution of plasma. Erythrocyte zinc concentrations were determined by the method of Rosney and Gorfren. ${ }^{11}$

For the oral plasma zinc tolerance test blood was taken from subjects to determine fasting plasma zinc after an eight hour overnight fast. A dose of $100 \mathrm{mg}$ hydrated zinc sulphate $(22.5 \mathrm{mg}$ elementary zinc) was then given. The subjects were allowed only water during the test. After the oral test dose of zinc, blood was drawn at one, two and four hours for measurement of plasma zinc concentrations. Using the data obtained, the increases in plasma zinc concentrations above fasting values were plotted. ${ }^{13}$ The control group was tested in the same way.

Mean (SD) values were calculated for all measurements. Student's $t$ test was used to assess the significance of differences between the groups. 


\section{Results}

Thirty seven malnourished children aged 5 months to 5 years and 10 healthy control subjects aged 6 months to 5 years were studied. Thirteen children had marasmus, 18 marasmic kwashiorkor, and six kwashiorkor.

Diarrhoea was present in $22(60 \%)$, oedema in

Table 1 Clinical and laboratory findings in 37 patients with protein energy malnutrition and 10 control subjects. Values are expressed as mean (SD)

\begin{tabular}{llll}
\hline & Patients & $\begin{array}{l}\text { Control } \\
\text { subjects }\end{array}$ & $\begin{array}{l}\text { P } \\
\text { Value }\end{array}$ \\
\hline Height $(\mathrm{cm})$ & $68 \cdot 8(13 \cdot 4)$ & $78 \cdot 0(9 \cdot 9)$ & 0.001 \\
Weight $(\mathrm{kg})$ & $6 \cdot 7(3 \cdot 2)$ & $10 \cdot 0(3 \cdot 2)$ & 0.01 \\
Mid arm circumference (cm) & $10 \cdot 4(2 \cdot 2)$ & $15 \cdot 4(1 \cdot 2)$ & 0.05 \\
Haemoglobin concentration (g/l) & $97(20)$ & $117(10)$ & $0 \cdot 01$ \\
Alkaline phosphatase activity & & & \\
$\quad(\mathrm{IU} / \mathrm{l})$ & $60 \cdot 7(38 \cdot 8)$ & $101 \cdot 7(39 \cdot 0)$ & 0.01 \\
Total protein concentration (g/l) & $55(10)$ & $69(5)$ & $\mathrm{NS}$ \\
Albumin concentration (g/l) & $35(9)$ & $43(5)$ & 0.01 \\
Globulin concentration (g/l) & $20(4)$ & $25(7)$ & $0 \cdot 01$ \\
\hline
\end{tabular}

five (14\%), anal, gluteal, and oral dermatitis in 19 $(52 \%)$, and hair loss in $26(70 \%)$.

Height $(p<0.05)$, weight $(p<0.01)$, mid arm circumference $(p<0.001)$, haemoglobin concentration $(\mathrm{p}<0.01)$, total protein and albumin $(\mathrm{p}<0.01)$, and globulin $(p<0.05)$ concentrations, and alkaline phosphatase activity $(\mathrm{p}<0.01)$ were signficantly decreased in the malnourished group compared with the control group (tables 1 and 2). The decreases in serum albumin concentrations were especially prominent in the patients with marasmic kwashiorkor and kwashiorkor $(p<0.05$ and $p<0.01$, respectively).

Plasma zinc and erythrocyte zinc concentrations and the results of the oral plasma zinc tolerance tests are shown in table 3. Plasma zinc and erythrocyte zinc concentrations were significantly lower in every subgroup compared with the control group $(\mathrm{p}<0 \cdot 01)$.

When patients with marasmic kwashiorkor and kwashiorkor were examined together after the zinc test dose had been given, the increase in plasma zinc was significantly less in the second hour compared with the control group $(p<0.05)$. On the other hand, the increase in plasma zinc was normal in the subgroup of marasmic patients (figure).

Table 2 Protein concentrations ( $g / l)$ in 37 patients with protein energy malnutrition. Values are expressed as mean (SD)

\begin{tabular}{llllll}
\hline & $\begin{array}{l}\text { Marasmus } \\
(n=13)\end{array}$ & $\begin{array}{l}\text { Marasmic } \\
k \text { washiorkor } \\
(n=18)\end{array}$ & $\begin{array}{l}p^{*} \\
\text { Value }\end{array}$ & $\begin{array}{l}\text { Kwashiorkor } \\
(n=6)\end{array}$ \\
\hline Total protein & $61(9)$ & $54(8)$ & $0 \cdot 01$ & $43(10)$ & $\begin{array}{c}p^{*} \\
\text { Value }\end{array}$ \\
Albumin & $39(8)$ & $35(8)$ & $0 \cdot 05$ & $26(8)$ & $0 \cdot 001$ \\
Globulin & $22(4)$ & $20(4)$ & $0 \cdot 001$ & $17(4)$ & $0 \cdot 001$ \\
\hline
\end{tabular}

${ }^{*}$ Compared with normal subjects.

Table 3 Zinc concentrations in 37 patients with protein energy malnutrition and 10 control subjects

\begin{tabular}{|c|c|c|c|c|c|}
\hline & \multicolumn{4}{|l|}{ Patients } & \multirow{2}{*}{$\begin{array}{l}\text { Control } \\
\text { subjects } \\
(n=10)\end{array}$} \\
\hline & $\begin{array}{l}\text { Marasmus } \\
(n=13)\end{array}$ & $\begin{array}{l}\text { Marasmic } \\
\text { kwashiorkor } \\
(n=18)\end{array}$ & $\begin{array}{l}\text { Kwashiorkor } \\
(n=6)\end{array}$ & $\begin{array}{l}\text { Total } \\
(n=37)\end{array}$ & \\
\hline Mean (SD) fasting plasma zinc $(\mu \mathrm{mol} / \mathrm{l})$ & $13.9(4 \cdot 6)^{*}$ & $15 \cdot 6(3 \cdot 7)$ & $13.0(2.9)^{*}$ & $14 \cdot 6(3 \cdot 8)^{* *}$ & $18.4(3.9)$ \\
\hline Median (range) & $13.8(6 \cdot 9-19.9)$ & $15 \cdot 1(6 \cdot 9-22 \cdot 2)$ & $12 \cdot 3(10 \cdot 2-16 \cdot 7)$ & $14 \cdot 4(6 \cdot 9-22 \cdot 2)$ & $19 \cdot 9(12 \cdot 1-24 \cdot 5)$ \\
\hline Mean (SD) erythrocyte zinc $(\mathrm{mg} / \mathrm{l})$ & $11.9(4 \cdot 3)^{*}$ & $8.0(2 \cdot 7)^{* * *}$ & $8.8(0.8)^{* *}$ & $9 \cdot 6(3 \cdot 7)^{* * *}$ & $17 \cdot 1(6 \cdot 0)$ \\
\hline Median (range) & $11 \cdot 4(5 \cdot 4-18.9)$ & $8 \cdot 2(4 \cdot 1-12 \cdot 9)$ & $9 \cdot 4(8 \cdot 2-18 \cdot 1)$ & $9 \cdot 1(4 \cdot 1-21 \cdot 7)$ & $18.5(10.4-23.9)$ \\
\hline \multicolumn{6}{|c|}{ Mean (SD) increase in plasma zinc $(\mu \mathrm{mol} / \mathrm{l})$ : } \\
\hline At one hour & $11 \cdot 4(5 \cdot 8)$ & $4 \cdot 8(4 \cdot 6)^{* *}$ & $5 \cdot 8(5 \cdot 3)$ & $7 \cdot 7(5 \cdot 7)^{*}$ & $12 \cdot 1(7 \cdot 6)$ \\
\hline At two hours & $18 \cdot 2(11 \cdot 0)$ & $10 \cdot 4(6 \cdot 8)^{*}$ & $8 \cdot 0(7 \cdot 6)^{*}$ & $12 \cdot 1(9 \cdot 2)$ & $17 \cdot 5(6 \cdot 5)$ \\
\hline At four hours & $6 \cdot 3(5 \cdot 6)$ & $3 \cdot 4(4 \cdot 2)$ & $2 \cdot 5(3 \cdot 6)$ & $4 \cdot 3(5 \cdot 6)$ & $2 \cdot 2(4 \cdot 5)$ \\
\hline
\end{tabular}

${ }^{*} \mathrm{p}<0.05 ;{ }^{* *} \mathrm{p}<0.01$, and ${ }^{* * *} \mathrm{p}<0.001$ compared with control subjects. 

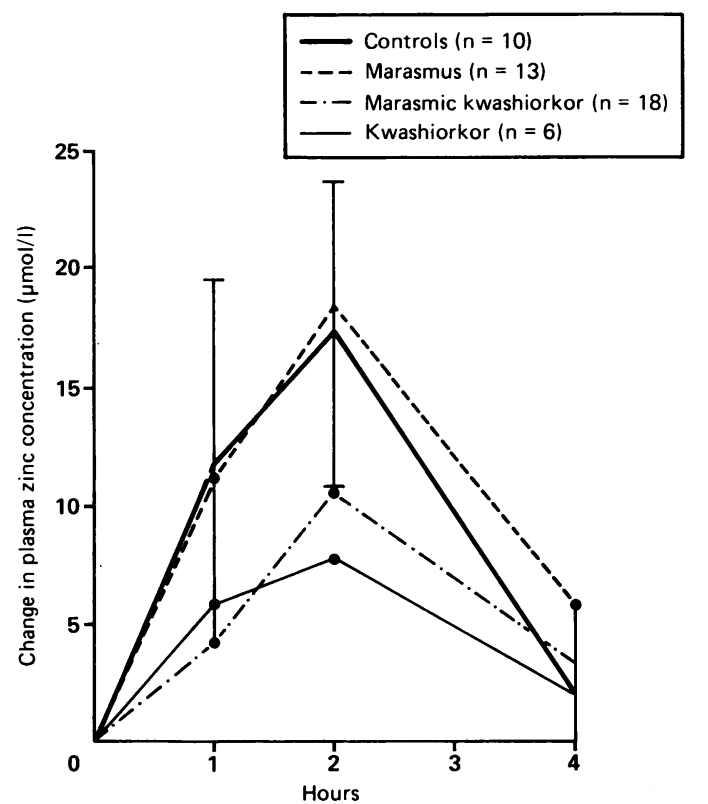

Figure Mean (SD) plasma zinc concentrations after oral plasma zinc tolerance test in patients with protein energy malnutrition.

\section{Discussion}

In this study alkaline phosphatase activity and plasma and erythrocyte zinc concentrations in patients with protein energy malnutrition were significantly lower than those of the control group.

There are several reports concerning zinc absorption in malnutrition. In some, zinc concentrations in plasma or serum were decreased ${ }^{13}$ while in others they were reported to be normal. ${ }^{24}$ Plasma zinc concentrations are not, however, good indicators of zinc state in man, because not only is plasma zinc turnover rapid, but many factors influence it. ${ }^{14}$ In order to study zinc state, therefore, we had to determine plasma zinc and erythrocyte zinc concentrations as well as alkaline phosphatase (an important zinc metalloenzyme) activity in our subjects. ${ }^{15-17}$

Zinc is required for normal growth and development, and deficiency can result from inadequate dietary intake, impaired absorption, excessive excretion, or inherited defects in zinc metabolsim. Requirements depend on the weight, age, and growth rate of children, and the bioavailability of zinc from different sources. Indeed, nutritional insufficiency was one of the main reasons for zinc deficiency in our group of patients.
The mitosis rate in the cells of the gastrointestinal, immune and haematopoietic systems is high. The effects of zinc deficiency as a result of the important action of zinc on protein synthesis, therefore, are observed mostly in these systems, so it is reasonable to claim that the chronic zinc deficiency in protein energy malnutrition might lead to pathological changes in the intestinal mucosa.

Many alterations in the gastrointestinal tracts of malnourished children have been reported. ${ }^{6-8} \mathrm{~A}$ genetic zinc deficiency disease, acrodermatitis enteropathica, causes severe intestinal mucosal atrophy, and zinc supplementation is effective in returning the mucosal to normal.

To measure intestinal zinc absorption the oral plasma zinc tolerance test was conducted in patient and control groups. The oral plasma zinc tolerance test, which measures the increase in plasma zinc concentrations, has been widely used as an assessment of intestinal zinc absorption. ${ }^{19} 20$

Under standard conditions the test gives valuable information about the absorption of zinc by the small intestine. Valberg et al compared radioactive zinc absorption with the oral plasma zinc tolerance test and found that the tests gave comparable results. $^{21}$ In both our subgroups of patients (marasmic kwashiorkor and kwashiorkor) the plasma zinc curve (figure) was significantly depressed compared with that of the control group.

In patients with marasmus, the plasma zinc tolerance test was normal, confirming the results of Brunser $e t$ al, who studied jejunal biopsy specimens of patients with marasmus and found normal mucosa. $^{7}$

We conclude that zinc deficiency in patients with protein energy malnutrition can induce intestinal mucosal changes that may aggravate the zinc deficiency, thus creating a vicious circle. It is therefore reasonable to give higher doses of zinc than are usually recommended when giving oral zinc supplementation to patients with protein energy malnutrition.

\section{References}

1 Kumar S, Rao KSJ. Plasma and erthrocyte zinc levels in protein carlorie malnutrition. Nutrition and Metabolism 1973;15:364-8.

2 Golden BE, Golden MHN. Plasma zinc and the clinical features of malnutrition. Am J Clin Nutr 1979;32:2490-4.

3 Golden MH. Skin breakdown in kwashiorkor response to zinc. Lancet 1980;i:1256.

+ Viteri FE, Behar M, Arroyave G, Scrimshaw S. Clinical aspects of protein malnutrition. In: Munro HN. Allison JB, eds. Mammalian protein metabolism. New York: Academic Press, 1956:523.

5 Gomez F, Galvan R. Cravioto J, Frenk S, Velazquez J, Pena C. Fat absorption in chronic severe malnutrition in children. Lancet 1956:ii: 121. 
${ }^{6}$ Mehta HC, Saini AS, Singh H, Dhatt PS. Biochemical aspects of malasorption in marasmus. Br J Nutr 1984;51:1-6.

${ }^{7}$ Brunser O, Reid A, Monckeburg F. Jejunal mucosa in infant malnutrition. Am J Clin Nutr 1968;21:976-83.

${ }^{8}$ Tandon BN, Magora M, Saraya AK, Ramalingaswami V. Am J Clin Nutr 1968;21:813-19.

9 McLaren DS, Read WW, Pellet PC. A simple classifing the severe forms of protein-caloric malnutrition of early childhood. Lancet $1967 ; \mathbf{i}: 533$.

10 Perkin E. Clinical method for atomic absorption spectroscopy. Connecticut: Perkin Elmer, 1973.

"Rosnev F, Gorfren PC. Erythrocyte and plasma zinc and magnesium levels in healthy and disease. J Lab Clin Med 1963;72:213-20.

12 Solomons NW, Jacob RA. Studies on the bioavailability of zinc in humans: effect of heme and non heme iron on the absorption of zinc. Am J Clin Nutr 1983;34:475-82.

13 Canfield WK, Menge R, Wolravens PA, Hambridge KM. Plasma zinc values in children recovering from protein energy malnutrition. J Pediatr 1980:97:87-9.

14 Baer MT, King JC. Tissue zinc levels and zinc excretion during experimental zinc depletion in young men. Am J Clin Nutr 1984;39:556-9.

15 Kasarskis EJ, Schuna A. Serum alkaline phosphatase after treatment of zinc deficiency in humans. Am J Clin Nutr 1980;33:2609-12.

${ }^{16}$ Reinhold JG, Kfoury A. Zinc dependent enzymes in zinc depleted rats, intestinal alkaline phosphatase. Am J Clin Nutr 1969;22:1250-1256.

17 Weismann K, Hoyer H. Serum alkaline phosphatase activity in acrodermatitis enteropathica. An index of the serum zinc level. Acta Derm Venereol 1979;59:89-90.

${ }^{18}$ Kelly R, Davidson GP, Townley RRW, Campbell PE. Reversible intestinal mucosal abnormality in acrodermatitis enteropathica. Arch Dis Child 1976;51:219-22.

19 Sullivan JF, Jetton MM, Burch RE. A zinc tolerance test. J Lab Clin Med 1979;93:485-92.

${ }^{20}$ Fickel JJ, Freeland-Graves JH. Zinc tolerance test in normal and zinc depleted humans. Fed Proc 1983;42:392-7.

21 Valberg LS, Flanagan PR, Brennan J, Chamberlain MJ. Does the oral zinc tolerance test measure zinc absorption. Am J Clin Nutr 1985;41:37-42.

Correspondence to Dr A Arcasoy, Kibris Sok 10/5, Güvenevleri Asaği Ayranci 06690, Ankara, Turkey.

Accepted 30 March 1989 